\title{
Work of the Chemistry Research Board
}

$\mathrm{T}$ HE report of the Chemistry Research Board* drawn up by the present director, Prof. G. T. Morgan, surnmarises the work carried out in the Government Chemical Research Laboratory during the first ten years of its existence, and is an impressive record of a large amount of valuable research in various fields. Much of the work has an industrial bearing, and there has been useful collaboration with several firms, mernbers of the staffs of which have been attached to the laboratory. A list of more than a hundred published papers is given, together with particulars of some thirty patents.

The first part of the report deals with researches on the corrosion of metals, which have had reference to the mechanism of corrosion in its relation to the prevention of rusting, tarnishing and corrosion of metals in industrial use. An anodic oxidation process for aluminium, in which the metal is protected by an oxide film produced electrically, was worked out, and a means of colouring aluminium has been adopted in industry. The protection of magnesium and its alloys, which are used in the aircraft, motor-boat and automobile industries, against corrosion by seawater and motor fuels, is being studied, as well as the corrosion of locomotive boiler tubes, zinc and purified iron and steels.

The report then deals with high-pressure investigations, including the synthetic production of alcohols from carbon monoxide and hydrogen, and acetic acid from carbon monoxide and ethyl alcohol. The starting point of these syntheses is represented by materials obtainable from coal. The equipment recently constructed is designed for work at 3,000 atm. at a temperature of $200^{\circ} \mathrm{C}$.

New methods of carbonising coal have led to the production of tars which differ considerably from those familiar in industry. New methods of separation

* Department of Scientific and Industrial Research. Report of the Chemistry Research Board for the Period ended 31st December 1934 . with Historical Introduction and Report by the Director of Chemical Research. Pp. $\mathrm{v}+94$. (London: H.M. Stationery Office, 1935.) 1s. $6 d$. net. have made possible the identification and classification of the components of tars produced by various methods. Certain tars contain phenolic constituents readily separable by distillation, and these, in solution in caustic soda, form a very efficient and cheap wetting-out agent for use in the textile industry, which is now marketed under the name of 'shirlacrol'. The application of high-pressure technique to coal tars has produced new compounds which have been tested for possible use in the dye industry.

A large amount of work has been done on synthetic resins, and a tough transparent resin has been obtained which resembles glass and may find application as a material for artificial dentures. Experiments with the object of making synthetic resins direct from tar oils indicate the possibility of simultaneously separating the valuable hydrocarbon oils. Resins formed in this way have been used for impregnation purposes, as they prevent the growth of mildew.

Since 1931, work has been proceeding in co-operation with the British Road Tar Association for the improvement in the efficiency and quality of road tars. It has been found that light, as well as air, may be important in connexion with the life of tar applied to roads.

Several problems concerned with micro-organisms have been dealt with. A method of preparing acetone-alcohol mixtures, useful as liquid fuel and otherwise, from straws and waste vegetable matter by fermentation has been demonstrated, and other investigations in this branch include the effects of micro-organisms in the deterioration of fabries and in tainting live fish in rivers, and the degumming of silk by lower fungi instead of acids.

The preparation and testing of synthetic drugs in co-operation with the Medical Research Council, the production of a base-exchange material for water. softening from British clays, the action of drinking water on lead, and investigations of the rarer metals are other branches of work described in the report.

\section{Conifers of the Balipara Frontier Tract, Assam}

\footnotetext{
TN the Indian Forester of May 1935 (61, No. 5, 1 Civil and Military Gazette Press, Lahore), Dr. $\hat{N}$. L. Bor, of the Indian Forest Service and at present political officer, writes on "The Conifers of the Balipara Frontier Tract, Assam". As a forest officer in Assam, Dr. Bor has taken full advantage of exceptional opportunities to study the forest flora of the more unknown parts of the country; some of his best work in the almost unknown region of which he is now in charge is briefly described in the article under review. The flora of this section of the Himalaya was practically unknown up to recent times and he set to work to collect, the considerable results of his activities being now under examination at the Royal Botanic Garden, Sibpur.
}

The area of the Eastern Himalaya in question covers an enormous tract of country exhibiting every variety of climate from that of the sweltering plains of Assam to the arctic climate of the eternal snows. Its northern boundary is the lofty Sela Range which sweeps north-eastward from the Tibet-Bhutan border and divides the Balipara Frontier Tract from Tibet proper. It contains a number of peaks more than 21,000 feet in height. Several travellers, Bailey and Moreshead, Kingdon Ward and others, have crossed the Sela pass into Tibet, but the southern slopes to the east are unexplored.

Dr. Bor gives details of the configuration of the region, its extraordinarily variable climate, its geo. logical features and inhabitants. A study of the latter 
would appear a sufficiently heavy task, for from west to east "are to be found Sherchokpas, Sherdukpen, Tembangias, Khoas, Akas, Mijis, Miri Akas, Daflas, Apa Tanangs and Miris, all differing in language, custom and dress. .. . The Western tribes are peaceful and well disposed to us. The Daflas and Apa Tanangs are, however, inclined to be truculent and it is impossible to tour in their country without an escort",

The conifers discussed in the paper are Pinus excelsa, $P$. longifolia (in extensive pure forests), Abies delavayi, in pure crops on the northern slopes of Piri, between $9,000 \mathrm{ft}$. and $10,727 \mathrm{ft}$.; its home is in Szechuan, China, this being a new record of its presence in Assam. Associated with it are species of Rhododendron, oak, etc.

Perhaps the most interesting of the investigations carried out are those recorded in connexion with Pinus excelsa. This conifer occurs in two places only - -the Tenga valley in the west and the Apa Tanang country to the east, two localities which are some 150 miles apart. In the Tenga valley the climate is dry, and the tree flourishes at between 5,000 ft. and $9,000 \mathrm{ft}$. Regeneration of the $P$. excelsa is very satisfactory if protection from fire is afforded.

The most interesting information with reference to this species comes from the Apa Tanang country. Here the rainfall is much higher, the elevation being $6,000-7,000 \mathrm{ft}$. The tree reaches a great size, $150 \mathrm{ft}$. in height with a girth of $14 \mathrm{ft}$. The wood of $P$. excelsa is used largely by the Apa Tanangs as fuel and for building material.

The most striking feature of this valley is the fact that the pine grows pure on the inner slopes only of the bowl, and pine trees are not found beyond the lip. On all sides the evergreen forest is apparently encroaching upon the pine, and dead pine trees can be seen emerging high above the evergreen forest on the inner side of the lip. A meticulous search in the pure pine forest failed to reveal a single seedling, showing that the pine seed cannot germinate and develop in the present conditions. It seems as if the pine is a remnant of a very large area of pure pine which is slowly dying out. In any event, it is clear that the Quercus-Michelia-Acer hylium is advancing upon it and will eventually prevail. This view is confirmed by certain of the Apa Tanang's elders, who told Dr. Bor that the area under pine has decreased even within their time, and that their forefathers had come to the same conclusion as that outlined above, and had as a consequence with considerable foresight ordered the tree to be raised in plantations. Seed is broadcast on hoed ground and the area protected from fire.

In the Zhob country of the Baluchistan frontier, the Sheranis attach equal value to the Pinus gerardiana both for its seed and timber, and endeavour to protect these forests from fire. But Dr. Bor's account of an aboriginal tribe successfully raising plantations by the cheap measures recorded must be unique.

\section{Broadcasting in India}

$\mathrm{T}$ $\mathrm{HE}$ growth of radio broadcasting during recent years has been so marked that in most of the larger European countries, in the United States of America, in Australia and in Canada, the number of registered listeners exceeds five per cent of the population. Actually, the number of licensed listeners in Great Britain and Northern Ireland at the end of 1934 amounted to about 15 per cent of the population. In India, however, with its population of more than 350 millions, the number of registered listeners is less than 12,000 , or about 0.003 per cent. This fact, with many others illustrating the very elementary stage attained by radio broadcasting in India, is given in a paper by $\mathrm{Mr}$. $\mathrm{K}$. Sreenivasan entitled "Development of Nationwide Radio Broadcasting in India", published in Electrotechnics for April 1935.

After reviewing the ideals and objects of a national broadcasting service in any country, Mr. Sreenivasan discusses the status of broadcasting in various parts of the world, illustrating the main facts with a useful table of statistical data. He then passes on to the consideration of a broadcasting scheme suitable for India to replace the three existing transmitting stations. The suggested scheme involves the installation of about five national transmitting stations and sixty regional stations, with an additional five short-wave transmitters for international longdistance broadcasting. The proposed distribution of these stations is illustrated by a map, and the scheme is considered to be adequate to serve all interests and requirements, having due regard to the various languages involved. In the matter of power allocation, each of the national transmitters would have $250 \mathrm{kw}$. in the antenna, the regional stations would vary between $25 \mathrm{kw}$. and $75 \mathrm{kw}$., while the short-wave stations would be of $50 \mathrm{kw}$. rating. This gives a total power of nearly $5,000 \mathrm{kw}$., or about one watt per square kilometre for India, as compared with the existing figure of about $2 \cdot 3$ watts per square kilometre for Great Britain.

With regard to the distribution of receivers, $\mathrm{Mr}$. Sreenivasan considers that, owing to the low standard of living prevalent in India, particularly in rural districts, there is no satisfactory alternative to community ownership of receivers and community listening. Even so, it is estimated that some $3 \frac{1}{2}$ million receivers will be required as an immediate objective.

The paper then proceeds to a consideration of the outline of an organisation of an autonomous public utility type for the provision, maintenance and operation of this national broadcasting service. It is suggested that a central broadcasting council should work under a Minister of Communications, and in co-operation with a number of provincial broadcasting commissions. Further sections are devoted to proposals for financing the project and to the policy underlying the programmes to be provided. In conclusion, the author modestly expresses the hope that his paper will help to create a correct perspective of the vast problem involved in the matter of broadeasting in India, and will provoke reasoned discussion on this national question. 